\title{
Shakespeare as National Discourse in Contemporary Children's Literature
}

\author{
Erica Hately
}

What these Tales shall have been to the young readers, that and much more it is the writers' wish that the true Plays of Shakespeare may prove to them in older years-enrichers of the fancy, strengtheners of virtue, a withdrawing from all selfish and mercenary thoughts, a lesson of all sweet and honourable thoughts and actions, to teach courtesy, benignity, generosity, humanity: for of examples, teaching these virtues, his pages are full.

(Lamb and Lamb 1953, p.17)

Writing for children is usually purposeful, its intention being to foster in the child reader a positive apperception of some socio-cultural values which, it is assumed, are shared by author and audience. These values include contemporary morality and ethics, a sense of what is valuable in the culture's past (what a particular contemporary social formation regards as the culture's centrally important traditions), and aspirations about the present and future.

(Stephens 1992, p.3)

Accepting Stephens' assertions about some of the cultural functions of children's literature, this paper raises the question of what happens in contemporary children's novels when that which is marked as 'centrally important' to both the child protagonist and reader is Shakespeare. More than that, I wish to examine the cultural complexities that are raised when that child protagonist — and often the implied reader-is Australian.

In conjunction with an understanding of the ideological and cultural functions of children's literature, Clare Bradford suggests that as a genre, it potentially offers insight into Australia's cultural understanding of itself, one which 'has since European settlement evidenced a gradual movement from dependence on the imperial centre to the development of an independent cultural identity. The colonial past is, however, still powerfully present in many attitudes and ideologies that appear natural until they are subjected to scrutiny, and Australian texts offer a rich field for such scrutiny.' (1996, p.92)

The continual negotiation of Australian identity that may be tracked in all cultural formations - including children's literature — can be seen as directly relevant to the place of
Shakespeare in contemporary Australian culture. The contemporary cultural climate is one in which we might view Barbara Freedman's description of Shakespeare as a 'privileged site of intersecting codes that reflect and effect discourse production and consumption' (1989, p.245) as representative. We no longer naïvely understand 'Shakespeare' as the author of a stable body of unified texts, but rather as a complex signifier of a variety of cultural codings and authorities, not confined to some ephemeral 'high culture' but continually expanding through overt integrations of Shakespeare into popular culture.

Despite an increasingly politicized critical environment, Shakespeare shows no signs of abdicating his cultural throne. Conversely, the exponentially expanding areas of critical and cultural enquiry guarantee his continued cultural centrality by developing and expanding Shakespearean cultural capital. In turn, it is not possible to 'ignore' Shakespeare, even if we should-in a postcolonial context-wish to. Michael Neill implicitly acknowledges this, with a particularly antipodean cultural context in mind, when he argues that:

the long and complicated history of Shakespeare's entanglement with Empire has ensured that (for better or worse) his work has become deeply constitutive of all of us for whom the world is (to a greater or lesser degree) shaped by the English language...Through four hundred years of imperializing history our Anglophone cultures have become so saturated with Shakespeare that our ways of thinking about such basic issues as nationality, gender and racial difference are inescapably inflected by his writing...the rehistoricization of Shakespeare that has taken place over the last two decades ought to make the study of his work in an antipodean context a more rather than less urgent priority. To cut oneself off from Shakespeare in the name of a decolonizing politics is not to liberate oneselffrom the tyranny of the past, but to pretend that the past does not exist. The question that needs to be resolved is not whether but how he should be taught. (1998, p.184)

Taking up Neill's 'call-to-arms', I wish to question here 
not why or whether Shakespeare is being taught to Australian children, but how he is being taught in a cultural, rather than an institutional, manner; specifically, via children's literature.

If 'Shakespeare' is a highly contested term, 'Shakespeare in/and Australia' seems to be even more problematic, and far less frequently considered. Clearly, this stems from the implied question of defining 'Australia'. Australian culture's general antipathy toward defining a national identity in terms any more specific than historical mythologies such as Anzac, mateship, antiauthoritarianism, and Henry Lawson, is naturalized as being 'laid-back', but could more critically be labelled lazy. I want to centralize the Australian cultural relationship with Shakespeare here, not least because it has consistently been effaced in the recent proliferation of critical enquiry into Shakespeare in contemporary culture. Within Australia, the 'Shakespeare in/and Australia' question, when addressed, has been taken to mean performance (Golder and Madelaine) or academic criticism (Craven) and appears to have been characterized by defensive cataloguing or facile nostalgia (respectively). Golder and Madelaine suggest_-in the seeming absence of an Australian poetics of Shakespeare-that 'what we now think of as our post-colonial approach appears to be more "laid-back", a term that is always likely to feature in any assessment of where we are now, and may amount to a casually subversive attitude.' (2001, p.12). Peter Craven, before longing for 'by-gone days' when there 'was a range of academic Shakespeareans in Australia', (2001, p.29) comments that 'Shakespeare in Australia is the topic I have been assigned, and there are moments when it can seem as absurd as Norway and the Pineapple.' (p.27). In each instance, prominent Australian critics do not ask how Shakespeare may be relevant to Australian culture, but rather, how Australian culture can or should rise to meet the high standards of Shakespeare.

We might compare this with the attitudes of American critics who, while acknowledging the ideological imperialism of Shakespeare cultural capital in/and America, nonetheless perceive a vigorous culture of engagement with Shakespeare that seems vastly different to the 'casual' Australian approach. Richard Burt, for example, among an extended examination of American popular culture responses to Shakespeare, notes that '[o]n the one hand, their postcolonial status makes Americans superior to the British: Americans have democracy and they don't. On the other, Americans remain culturally inferior: Shakespeare remains the measure of American culture.' (1998, p.138) This ambivalent relationship between Shakespeare and America is often described by cultural critics in filial terms. Hence, Michael Bristol explores ' $\mathrm{t}]$ he idea that Shakespeare is a founder or creator of a specifically American experience of individuality and of collective life' (1990, p.3) and expresses concern that 'the notion of a critique of Shakespeare...implies that Shakespeare might be something to become emancipated from rather than something to be emancipated by' (1990, p.5), while Thomas Cartelli calls Shakespeare 'a virtual founding father' (1999, p.2), even as he notes that 'U.S. transactions with Shakespeare specifically witness the failure to develop models of democratic subjectivity that could be said truly to break from the critically established heroic, individualist, and paternalist bias of Shakespearean drama.' (1999, p.2).

I bring in the American perspective here not to displace my Australian enquiry but to contextualize it. Similarly, in order to delineate a clear understanding of a specifically Australian juvenile relationship with Shakespeare, and its resonances within Australian culture generally, I will be reading Robin Klein's Penny Pollard's Passport, and comparing its deployment of Shakespeare as cultural authority with that of the American novel King of Shadows by Susan Cooper. ${ }^{1}$ In doing so, I intend to demonstrate that children's novels that use Shakespeare both exemplify and perpetuate certain cultural anxieties about the colonial/ postcolonial child's relationship with Shakespeare as emblem of English culture in general. In other words, I wish to examine the methods and possible motivations of these texts' 'transmissions' of cultural values and assumptions, specifically, values and assumptions regarding national cultural identity. When Laurie Osborne notes that 'the production of Shakespeare for young children not only exposes how a culture imagines the education of its young people but also how reworking Shakespeare for children justifies a revealing degree of 
abbreviation, naturally only in preparation for the "real thing." (1997, p.103) she does not note that the nature of these 'preparations' varies greatly from nation to nation and in turn indicates an ongoing struggle involved in the development of an autonomous national identity that is at once Australian/American, but that can also engage with Shakespeare as a kind of 'poster-boy' of English culture.

In each of these novels, we are introduced to child protagonists - Penny Pollard and Nat Field — who seem to see and understand many things that the adults around them do not. This is not surprising in the context of contemporary children's literature; my interest here is not in 'what' they understand so much as 'how' they understand it. This paper attempts to read the understandings of these children as part of their broader cultural context, with particular interest in their status as colonial/postcolonial subjects involved in their first personal engagements with a colonial 'point-of-origin' and how these engagements both exemplify and reproduce certain cultural anxieties about relating to and with Shakespeare in the contemporary cultural environment. The 'mother country' is a more influential discourse for Penny than the 'father figure' is for Nat. I intentionally use these kinds of parent-child terms for their relationships with English culture and Shakespeare (as emblem of English culture), because their nations are engaged in similar kinds of parent-child relationships articulated as a colonial relationship. If so, we might view America as the elder sibling, who has separated from the mothercountry (England) and can now embark on an Oedipal relationship with the father figure of English culture, Shakespeare, such as that described by Burt and Bristol. Comparatively, Australia may be viewed as the younger sibling, still involved in a maternal-symbiotic relationship with England. So, where America is negotiating a postcolonial cultural relationship with England, Australia would seem to be engaged in a colonial one. These are of course not simple categories, but they nonetheless seem appropriate when we consider the forms and motivations of Penny and Nat's separate travels to, and direct interpersonal engagements with, both England and Shakespeare. Just as 'Shakespeare' is able to function as a symbolic representative of English culture, so do the protagonists of these novels function as symbolic representatives of their nations as 'child' in the colonial context.

Further, just as Penny and Nat function as symbolic embodiments of their country's child-like relationship with a parent culture, so do the general textual practices of children's literature lend themselves exceptionally neatly to questions of 'cultural education' as a central focal point. Where adult literature that appropriates Shakespeare presumably can 'cash in' on a shared audience sense of Shakespearean cultural capital, children's literature is conceivably obligated to establish Shakespeare as culturally important and relevant before deploying him as authoritative. We see this achieved when the protagonists 'independently' recognize the value of Shakespeare, and integrate him into their personal cultural value systems. We may also consider the filial status of these children on the journeys to England. Nat is literally an orphan, while Penny travels with a surrogate mother, Mrs Ross; removed from literal parental control, they are both freed to engage symbolically with England as parentculture.

John Stephens describes children's literature as being 'grounded on the premise that what this otherwise rather amorphous body of texts has in common is an impulse to intervene in the lives of children. That is, children's fiction belongs firmly within the domain of cultural practices which exist for the purpose of socializing their target audience.' (1992, p.8). In short, a text is considered appropriate for children if it contains some inherent 'moral', or a discourse in keeping with the broad values of the society in which it is produced and read. We expect children's literature to further children's understanding of both their world/society/culture, and their place in that society from two perspectives: their accepted roles as children; and, their projected roles as adults.

The second primary condition of children's literature may be describe as that of 'entertainment'. We tend to assume that a juvenile reader is unlikely to 'sit still' for a dry moralistic tale, particularly in the latter twentiethcentury where children's literature meets competition in a multimedia-driven cultural environment. I am taking as a 'given' the assumption that the texts I am exploring 
have entertainment value for a juvenile audience, for if they did not, market forces dictate that they would no longer be in print. However, I believe the subordination of entertainment to education can be somewhat ameliorated by the deployment of Shakespeare, as he is perceived by 'adult culture' as serving both needs.

Whereas we have seen Shakespeare-for-children used as texts of social and moral instruction and control (I am thinking especially here of the Lambs' Tales from Shakespeare and E. Nesbit's Beautiful Stories from Shakespeare) more recent children's appropriations appear to deploy Shakespeare as object, rather than as weapon, of scrutiny and political critique, while maintaining a generally conservative understanding of Shakespeare's broad cultural function. This not only offers readings which are both accessible and relevant to the intended audience, but also transmits Shakespeare as artifact of cultural authority to a new audience.

This potentially sets up a disjunction between radical and conservative cultural functions of Shakespeare. This disjunction is heightened in the postcolonial context where Shakespeare is not just a figure of authority, but one of English authority.

It is to engage with this seeming contradiction that I wish to introduce intra- and extra-textual readings as a method of attempting to distinguish between the overt, and diegetic, functions of Shakespeare. Although these texts happily engage intra-textually with individual plays/ characters/events that take place within Shakespearean text, they maintain a conservative extra-textual perspective on Shakespeare as a cultural icon and reproduce Shakespeare as a discourse of cultural authority even in the postcolonial context. This means that the commitment to both the reader's and the protagonist's entry into an existing liberal-humanist conception of maturity is privileged over any goals of critiquing that culture.

The most obvious antecedent of children's Shakespeare is the volume Tales from Shakespeare by Charles and Mary Lamb. For the Lambs, the purpose of their task was relatively simple: 'to find a moral meaning' for each of the plays they relate. Their preface to the first edition of Tales, published in 1807, makes clear both their intentions, and intended feminine audience:
For young ladies too, it has been the intention chiefly to write; because boys being generally permitted the use of their fathers' libraries at a much earlier age than girls are, they frequently have the best scenes of Shakespeare by heart, before their sisters are permitted to look into this manly book; and, therefore, instead of recommending these Tales to the perusal ofyoung gentlemen who can read them so much better in the originals, their kind assistance is rather requested in explaining to their sisters such parts as are hardest for them to understand: and when they have helped them to get over the difficulties, then perhaps they will read to them (carefully selecting what is proper for a young sister's ear) some passage which has pleased them in one of these stories, in the very words of the scene from which it is taken; and it is hoped they will find that the beautiful extracts, the select passages, they may choose to give their sisters in this way will be much better relished and understood from their having some notion of the general story from one of these imperfect abridgements; - which if they be fortunately so done as to prove delightful to any of the young readers, it is hoped that no worse effect will result than to make them wish themselves a little older, that they may be allowed to read the Plays at full length (such a wish will be neither peevish nor irrational).

(Lamb and Lamb 1953, p.17)

The inscription of a gendered, passive audience here clearly marks the Lambs' investment in conservative culture, and it is reasonable to assume that this conservatism influences their methods and means of appropriation. Indeed, as a model of appropriation, the Lambs' text reveals both overt and covert moralizing, wilful 'interpretation' disguised as abridgement, and the forcing of a unilateral meaning onto both the play and the designated audience. Significantly, the third-person narrative is constructed so specifically as omniscient that no character is allowed to function as 'focalizer', neither to offer alternative perspectives on events, nor to offer the reader an opportunity to critique the authorial position. Although the Lambs' text is still in print it seems unlikely as a popular choice for contemporary juvenile audiences, but it offers a wonderful example of the extent to which selective retelling can enable very specific political goals. 
These appropriations, under the guise of simplistic retelling, actually recast the plays as specifically moral fables, enforcing contemporary gender values as timeless and authoritative. I would argue that the Lambs' text differs from contemporary appropriations not in its intent, but its methodology, and its seeming lack of interest in offering any kind of direct point of identification for a child reader. The Lambs are far more committed to maintaining difference-between the past and the present, and children's and adult culture, and both intra- and extra-textually-focusing on the didactic potential of Shakespeare, than in encouraging any kind of critical thought in children. In the contemporary texts we see this didactic valorization of Shakespeare performed covertly, and naturalized as the protagonists' own choices rather than the adult cultures. ${ }^{2}$

Our contemporary child protagonists are not, as in the Lambs' volume, inscribed as passive textual readers. Rather, they are set up as 'cultural' readers who engage with enactments and representations of Shakespeare in England. However, even their means of travel, and ostensible purposes for travel, quickly articulate very different cultural orientations. Penny wins a holiday, which is quickly turned into an educational visit: she is given homework assignments, is instructed to "not give Australia a bad name', (Klein 1999, p.5) and is essentially groomed to encounter Britain as origin. In comparison, Nat 'earns' his trip to England, and there is a sense in which the theatrical troupe he travels with are there to teach rather than to learn. Their task is to perform plays 'the way they were four hundred years ago.' (Cooper 2000, p.5).

In comparison with the Lambs' use of Shakespeare, Robin Klein deploys Shakespeare in Penny Pollard's Passport (1988) citationally, and does not attribute her citations. Rather, Shakespeare functions as a significant element in a broad British cultural authority against which her protagonist struggles to develop and maintain an independent, and distinctively Australian, identity. Here, the theme of the 'mother-country' is heavily endorsed, particularly as Penny is travelling with a surrogate-mother while her own mother remains in Australia. Although Penny gamely questions the authenticity of some sites, and insistently attempts to find personal meanings in spectacles and events, she nonetheless accepts that the British culture is antecedentand ultimately superior-to her own. Klein may attempt to participate in myths of Australian identity (such as independence of spirit, friendship, a lack of interest in class-based social hierarchies and 'instinct' over intellect) but these myths are in themselves forms of constructing Australia as infantile, the wilful child of Great Britain, possibly the cultural black-sheep of the Empire, but a member of the Commonwealth nonetheless. The extent to which Penny is ultimately co-opted by these discourses is revealed by her seemingly voluntary focus on 'Shakespeare' as the apotheosis of the very British culture she seems uninterested in, and her ultimate declaration about a tourist site that 'the only thing missing was Shakespeare!' (Klein 1999, p.101).

Commencing in 1983, with Penny Pollard's Diary, and continuing over five books, Penny has been popular as the protagonist of first-person accounts of life in suburban Australia and is a familiar figure to Australian child readers of the 1980s. Her accounts are simultaneously irreverent and naïvely accurate. Similarly, Robin Klein is well known in Australian children's literature, having been at the forefront of the industry for over twenty years, and the recipient of several awards.

Penny's major defining characteristic is that of being a 'tomboy'. This effectively removes her from idealized portraits of 'little girls with golden curls', as she would much rather play football, grow mushrooms and design her own battle-jackets than be a flower-girl, learn ballet or play with dolls. She provides a contemporary counterpoint to the mealy-mouthed implied audience of the Lambs' versions of Shakespeare: she is not the passive young lady, waiting for a moral guiding hand; rather, she is an active and assertive child who wishes to develop an independent identity. In juvenile terms Penny refuses to accept the prescribed behaviours and attitudes of femininity suggested to her by her family and society. In fact, Penny refuses to acknowledge gender division at all. Naturally, this kind of wilful refusal is only possible in the pre-adolescent/pre-sexual days, and it must be noted that despite Penny's seeming subversiveness, each 
of the texts sees her learning a 'valuable life-lesson' which ultimately enforces the very adult culture Penny seems so committed to undermining, and confirms the conservatism of children's literature.

In Penny Pollard's Passport (1988), an epistolary text made up of letters, notes and diary entries, Penny travels to Great Britain with her best friend Alistair Ross (and his mother) after he fraudulently wins the major prize of a trip for two through their local supermarket. Alistair's mother acts as chaperone to them after a successful negotiation with supermarket authorities, who acknowledge that 'as you've correctly pointed out, there were no stipulations in the conditions of entry regarding age.' (Klein 1999, p.4). Notably, this negotiation sets a symbolic precedent for Penny's dealings with the majority of authority figures she encounters while in Britain, a kind of conservative transgression which usually results in Penny's willing acceptance of adult authority rather than a sustained rejection of it.

From her first letter, Penny reveals the constant adult concern about how she 'represents' Australia, and also that the trip is to function educationally. Her teacher sets an assignment to write about 'Three Important Historical Sites in England'(Klein 1999, p.5). This assignment simultaneously marks England as a location of historical interest and authority. Penny is therefore engaging with a very specific discourse of Australian subordination to English culture before the trip even commences. Significantly, Penny will later arbitrarily alter this assignment to 'FAMOUS ENGLISH HISTORICAL PLACES (AND PEOPLE)"'(p.75) so that she can include William Shakespeare. This action maintains her pattern of limited rebellion authorized and endorsed by the English culture she has effectively been instructed to revere. Even further than this, the 'Shakespeare' she writes of is as much the cultural commodity represented in Stratford-on-Avon as the playwright.

Their arrival in Britain establishes Penny's self-perception:

I felt I was representing Australia in that long queue. Landing in England was like a 200-yearold link with great-great-grandfather because he was a convict (even though Aunt Winifred still says he was actually the chaplain on the convict ship and didn't believe all those photocopies Dad got from Trace-Your-Ancestry).

(Klein 1999, p.10)

Penny Pollard's Passport then, differs from the other Pollard books, in that it places Penny in a situation that forces her to consider her national identity. Very quickly, we become aware that Penny's understanding of this aspect of her identity is tied up with certain national myths of character and integrity. Penny's identification as Australian before anything else (such as gender) does not result from a veneration of Britain, nor entail mutely accepting any perceived offences; nonetheless, she ultimately learns to subordinate certain discourses of 'Australianity' to the superior English culture. Penny is deeply proud of her Australian identity, and presumes that its inherent value can only be reduced by specifically 'unAustralian' actions or ideas. In extension, she does not perceive Britain passively; for her, the British history and culture she encounters only has meaning if she can contextualize it within her Australian lifestyle and identity. This may be seen as a valorization of Australian 'directness', but ultimately enacts a cultural colonization. For example, a visit to Glencoe is of interest because she can take souvenirs home to Campbells and MacDonalds she knows in Australia; her visit to King's College Chapel is described as "all white and lacy like being inside a giant pavlova."'(p.15). In the very moments she seems to be asserting Australian understanding, she is nonetheless incorporating these British landmarks as significant into her cultural lexicon. She is not importing Australian language or ideas into England, but rather using them as a facilitator of taking these English elements home with her.

Penny's encounters with the 'otherness' of British culture is mirrored personally by her encounters with Heidi Denver, a young girl on the tour-also Australian-who it becomes clear is a kleptomaniac, antisocial and pretentious. Heidi functions almost as Penny's doppelgänger in that she openly denigrates Australia, seems to have no interest in 'learning' about England, and is actively rude to almost everyone she meets. As the text progresses, it becomes clear that Heidi has had a difficult childhood and uninterested parents. This information not 
only goes some way to making her an object of sympathy, both to Penny and the reader, but allows Penny to learn the all-important personal lesson of the value of strong parental guidance. After realizing that Heidi has been stealing because she receives no genuine parental care from her mother, Penny notes that 'I turned away and went quickly after Mrs Ross, understanding a bit better why Heidi collected all those pathetic little goodies for herself.' (Klein 1999, p.122). In this text, where British culture and adult authority are closely conflated, Heidi also functions as a cautionary presence that Penny- the 'open-minded' young girl-has instinctively grasped. Throughout the earlier sections of the book, we hear constant worries from Penny about Heidi, not for her personal welfare, but her national integrity:

\section{'don't blame me if Heidi gets arrested AND} GIVES AUSTRALIA a bad name' (p.34)

'Supposing she ends up being arrested and the goodname of Australia will be disgraced?' (p.43)

'Getting wet in the rain is better than letting Australia be disgraced by a little crook!' (p.84)

Ultimately, Penny and her friend Alistair manage to 'redeem' Heidi, or at least begin to, and Heidi's attempts at reformation are ultimately symbolized by her buying a large stuffed lion from Harrod's when Penny cannot afford it. Again, commodified symbols of Britain serve to indicate character development.

Unsurprisingly, one of the stops on their bus-tour around the United Kingdom is at Stratford-on-Avon. The reader is very quickly introduced to the commercialized aspect of the town, as Penny travels to Anne Hathaway's Cottage and other sites. Shakespeare does not appear as an individual, but rather as a commercial or cultural construct. Shakespeare as extra-human is therefore removed from a specific national or historical identity and can effectively function as a mediator between self and other, or as an eraser of difference. That said, this effacement of difference, much like Penny's effacement of her gender, can necessarily be only temporary. Furthermore, the 'Shakespeare' invoked in Stratford is divorced-at least initially for Penny-from the playwright Shakespeare. Part of her 'English education' may be understood as learning to integrate Shakespeare the playwright and Shakespeare the tourist industry into a unified authority figure, and emblem of English culture.

While she attempts to conjure up an imaginary historical Shakespeare, contemporary - and it is implied, baserculture continually intervenes. Even when she appears to be critiquing the commerciality of the town, Penny is nonetheless being converted to the cult of Shakespeare, and starts collecting her own 'relics'. Taking some examples together, we can see how Klein's perfunctory technique of 'Australian plain-talking' begins to accrete as a failed debunking of the very cultural capital that the novel is participating in, and ultimately reproducing:

I also saw the school where he went though he probably didn't like it very much because kids in those days had to go to school from 6 a.m. ...Kids came out every now and then but they didn't take any notice of all the tourists craning over the front fence. (Klein 1999, pp.76-7)

I also went to the church where Shakespeare was buried and there were more tourists all standing there with very holy faces looking down at this slab with his name carved on it. ...I reckon they could have given him a fancier gravestone. (p.77)

Outside in the churchyard I picked up a pebble just in case Shakespeare had touched it...maybe Shakespeare had once chucked it at a kid he didn't like from school. (pp.77-8)

Penny is not overwhelmed or overawed by Shakespearean mythology or cultural authority. Rather, she appropriates the language of Shakespeare and makes it a living component of her own life. For Penny, Shakespeare is valuable neither for insights into the human condition, nor as the author of great literature, but as the author of great insults:

I found these threats and insults:

1) Turn thee, Benvolio, look upon thy death! (20 th century translation: You chicken or something?)

2) Have at thee, coward! (Take that, you wimp!) 
3) The devil himself could not pronounce a title more hateful to mine ear! (You give me the irrits, Jason Taylor, and so does the sound of your name!)

4) Thou liest, abhorred tyrant! (It's not fair, you said I could stay up and watch that late movie!)

5) a) You stubborn ancient knave, you reverent braggart!

b) O inhuman dog! (Both general purpose insults)

6) What bloody man is that? (sounds really modern.) (Klein 1999, pp.78-9)

For Penny then, Shakespeare expands rather than instructs. She encounters the plays directly (albeit minimally) and finds her own meanings, effectively enacting an 'ideal' first reader unfettered by pedagogical or moralizing 'editors'. For the child reader, Shakespeare is not reproduced here as a specific body of work, but as a producer of interesting and useful language, practical rather than cultural knowledge. The non-specific mode of citation does not alienate a reader from a seemingly monolithic and distant 'Shakespeare', but rather offers a small sample of relevant material, and perhaps encourages a young reader to source the quotes for themselves. However, it also appears to the reader as a 'first-encounter', and it is easy to suppose that Penny herself will return to the plays again and again as she matures, and in extension, presumably acquire more and more cultural knowledge.

Penny's relationship with Shakespeare is the apotheosis of her relations with all things British. There is a distinctly nationalistic element to Penny's encounters with Britain and the British: she is more than happy to value anything she learns or finds relevant to her own life, but her highest priority on the trip is 'not [to] give Australia a bad name' (Klein 1999, p.5). Penny is successfully inducted into the wonder of Shakespeare's language without any critical engagement with the legitimacy of its authority. It is at this point that we must consider the intra- versus extratextual functioning of Shakespeare in the novel. Intratextually, Penny appropriates the language of Shakespeare seemingly of her own accord, and in keeping with her identity as established by the text, does not seem to deify
Shakespeare because of any specific cultural associations, but because she enjoys the language for itself. Contextualised among Penny's many 'adventures' in Britain, Shakespeare would seem to play a minor role in the text. However, the fact that he is the only 'person' on whom she writes one of her compulsory school assignments (basing the other two on historical sites) could be read as Klein's extra-textual endorsing of the general cultural authority of Shakespeare above any other historical personage, despite her protagonist's rejection of any such broad authorities. Beyond this, Shakespeare is clearly marked as superior to any national prejudices Penny may appear to hold. Klein has made 'Shakespeare' into a figure of historic, literary, personal and public interest. In this sense, she replicates Freedman's 'competing discourses', allows Penny to write them into a unified lauding, and transmits them wholesale to the contemporary Australian child as an object of admiration and enquiry. It would therefore seem to me that in this instance, we are reading a colonial cultural coding being conducted under the guise of postcolonial criticism.

This colonial cultural anxiety is thrown into sharp relief when compared with Susan Cooper's 1999 novel for adolescent readers, King of Shadows. Cooper installs Nat Field, a teenage 'prodigy' actor and orphan, raised in the United States and drafted into a youth Shakespeare company for a performance of A Midsummer Night's Dream in London at the Globe Theatre, as an authentic inheritor and articulator of Shakespeare.

The Company of Boys, chosen by Arby and his committee from schools and youth theatres all over the United States. We were all shapes and sizes and ages, up to eighteen; the only thing we had in common was that, by accidentor experience or both, we all knew how to act. Supposedly we were the best young stage actors in the country. (Cooper 2000, pp.4-5)

Through an unexplained - read fantastic - turn of events, Nat finds himself in Elizabethan London, performing in The Chamberlain's Men with Richard Burbage, and most significantly, Shakespeare himself. Having exchanged physical and temporal locations with the 'real' Nat Field, Nat quickly overcomes language barriers to revolutionise 
a Royal Command performance of the play, and establishes a filial relationship with the historical Shakespeare that in turn enables him to reconcile the death of his own father in the late twentieth-century. This variant on the psychological quest effectively 'equalises' the cultures of both imperial Britain and postcolonial America.

Where Penny is continually marked as Other by her cultural identity, Nat's markers of cultural difference paradoxically authenticate him in Elizabethan London:

\begin{abstract}
'Nat-Arbyknows as well as I do that you probably sound more the way they did in Shakespeare's time than anyone in this company. Or even any English actor.'

I looked at her sceptically.

'It's true,' she said. 'The English and the Scots who settled those North Carolina and Georgia mountains of yours, they took their accents with them. And because they didn't hear too much else up there, they didn't change, the way everyone else did.' (Cooper 2000, p.17)
\end{abstract}

Whereas the Australian relationship is articulated as one of super and sub-ordinate, the American is presented as newly equalised. Nat is able to engage with Shakespeare as an individual person, where Penny-having tried, and failed, to imaginatively capture a living Shakespeare separate from the tourist attraction - is forced to turn the plays into disconnected texts with which to form a living and authentic relationship.

In comparison to Klein's text, where Shakespeare is invoked as an object of cultural tourism, a weapon of continued British imperialism, Cooper's Shakespeare is literally a living, breathing person with whom Nat is allowed to establish a significant and exclusive personal relationship. And, where Penny connects with Shakespeare's plays as 'floating signifiers'-inherently valuable, but only when disconnected from their cultural context -Nat is active in the very production of such cultural contexts.

For Nat, American culture is the normative, and English the variant, 'An English taxicab wasn't a normal yellow cab...' (Cooper 2000,p.13). This confidence undoubtedly facilitates the effective erasure of four centuries of English culture when he travels back in time, literally achieving what Penny is unable to do symbolically. Although Nat confesses to displacement, it is couched in temporal and technological terms rather than in national cultural ones:

There was hardly a moment when I wasn't aware that I didn't belong. I suppose a lot of it was what they call culture shock: the business of suddenly finding yourself without all the little everyday goodies that a kid living in the twentieth century takes for granted. (p.65)

Once in Elizabethan London, Nat's accent and actor training enable him quickly — and relatively easily - to assimilate into the local culture. Joining the Chamberlain's Men, he is able to draw on his pre-existing knowledge of A MidsummerNight's Dream to consolidate the legitimacy of his place there. While this obviously validates knowledge of Shakespeare as socially useful, it also compounds Nat's place in a surrogate family,

\section{I was as happy that moment as I think I'll ever be: standing there listening to [Shakespeare], knowing I was part-and a useful part, just now-of his company, safe in the small family world of the theatre. I wanted it never to end. (Cooper 2000, p.92)}

Although Nat meets or at least encounters numerous significant figures from the Elizabethan theatre world Richard Burbage, Will Kempe, Heminge, Condell and of course, Queen Elizabeth herself — it is the relationship with Shakespeare himself that is marked as centrally important to Nat. This is true in the filial and cultural sense. Shakespeare is transformed into the ideal father that Nat has been longing for. In an emotionally climactic scene, Nat confesses the truth about his own father's death to Shakespeare (and necessarily the reader). Mourning for his wife, Nat's father - also a writer - has committed suicide, and Nat has discovered the body. This confession, the equivalent of the psychoanalytic breakthrough, positions Shakespeare as an absolute parent, able both paternally and maternally to act as audience to Nat's confessions of feeling guilty, and offer comfort that is not only immediate and physical, but also long-term and emotional: 
He sat down abruptly on the stage, pulling me down with him, and sat there with his back against the great wooden pillar while I sobbed into his shoulder. He didn't try to stop me, he just waited, patting me gently, saying very softly once in a while, like a mother to a very small child, 'There. There now.' (p.70)

'Listen to me,' he said. 'Do not say thou wast not enough for thy father. Never say that. Some things are beyond our command. A man so caught and held - men will destroy much for love, even the lives of their children, even their own lives. I have a poem that I shall copy for thee, that thou shalt read and remember. Remember.' (p.72)

This encounter, while compounding and confirming a sense of parent-child connection between Shakespeare and Nat, has also, we soon learn, functioned as a catharsis. After moving into Shakespeare's house — a symbolic adoption - Nat realises 'I was thinking about him, without panic or tears, in a way I hadn't done since he died.' (Cooper 2000, 79). Thereafter, Nat finally describes the relationship between himself and Shakespeare, acknowledging the degrees of transference and substitution that characterise it:

\section{Shakespeare put his hand on my shoulder. He was thinking of me as the orphan boy, I knew; thinking my head was haunted only by the death of my father - as it had been too, until now. Perhaps he was thinking of his own boy Hamnet as well. (p.100)}

Simultaneously with the development of this pseudofilial relationship, we also witness the development of a textual/cultural relationship between Shakespeare and Nat. Shakespeare presents him with a copy of the poem we now know as Sonnet 116, 'Let me not to the marriage of true minds...', telling him, 'It is about love, and loving. I wrote it for a woman, but it could just as well be for thee and thy father. I give it to you to remind you that love does not vanish with death.' (Cooper 2000, p.101). Here, Shakespearean text is established as holding universal and useful truths. Reading the poem aloud to Nat, Shakespeare effectively establishes his own poetry as a substitute for himself.
This substitution is significant as it participates in a general cultural canonisation of Shakespearean text as a 'repository of truths' and also offers Nat a permanent connection with Shakespeare not dependent on physical or temporal proximity. This is particularly important for the inevitable return to the twentieth-century that Nat seems not to be considering.

Shakespeare and Nat are further culturally linked by their successful performance together as Oberon and Puck in a 'royal command' performance of A Midsummer Night's Dream. Nat values the applause they receive from the audience far more than the compliments paid him by the Queen herself.

The following morning, Nat wakes up in contemporary London. Removed from his newly gained haven, surrogate family and sense of security, Nat must learn to integrate his 'Shakespearean' and 'ordinary' selves. Again, this adjustment takes place in both the filial and cultural sense. Nat must not only reconcile the seeming loss of a second writer-father, but also come to terms with Arby's challenging twentieth-century production of the Dream.

Nat finally articulates his grief and anxiety in a sentence that could easily refer to either to Shakespeare or his father: 'I loved him and I missed him, and I should never see him again.' (Cooper 2000, p.159). His engagement with the historical Shakespeare therefore enables Nat to articulate and understand the 'human condition', individually enacting the general claims made for Shakespeare's plays in Western culture by critics like Harold Bloom: 'We all of us were to a shocking degree, pragmatically reinvented by Shakespeare. Our ideas as to what makes the self authentically human owe more to Shakespeare than ought to be possible.' (Bloom 1998, p.17).

However, Nat's journey into the past would not fulfil the 'quest' requirements of children's literature if it were not understood by the protagonist as having resolved a personal issue. The solipsism of the child protagonists demands personal and clear understanding of benefits, and indeed, Nat demands this kind of confirmation, ' $I$ was the one he rescued from the pit I was in. But why have Ihad to lose him?' (Cooper 2000, p.166) Nat's opportunity 
to engage with Shakespeare - and thereby resolve his emotional turmoil about the death of his father - is justified as having literally saved Shakespeare's life:

\begin{abstract}
'It was 1599, Nat,' Rachel said. 'Shakespeare was only in his thirties, he wrote most of his greatest plays after that. If he'd acted with Nat Field instead of with you, he'd have caught the plague and died.'... 'We'd have lost the best playwright that ever lived. You may feel you've lost him, Nat, but you saved him. If you hadn't gone back in time, William Shakespeare would have died.' (p.169)
\end{abstract}

Here then, Nat has been able to save the life of a father figure as he was unable to do with his own father, and in so doing, has ensured the production of Shakespeare's 'greatest plays' and also saved the great father figure of Western culture. By extension, Nat is implicated in the very creation of the plays, a fact which marks him as a legitimate 'heir' of Shakespearean discourse: a contemporary mirroring of the legitimacy his accent lent him in Elizabethan London. Broadening this to a national cultural discourse, we may understand that America is being installed as the legitimate heir of Shakespeare, capable of immediate and insightful understanding of the texts based not on four centuries of cultural tradition, but rather on an intuitive connection with the plays themselves. This presents us with a narrative demonstration of Charles Marowitz' assertion that 'Although the people in Shakespeare's plays still speak like Britons, they "feel" and "act" like Americans-that is to say, obsessively, athletically, dramatically and emotionally.' (1991, p.117).

Nat is somewhat satisfied by this knowledge, but it is really Arby's ${ }^{3}$ final piece of information that establishes a link between Shakespeare-again replaced by his textsand Nat that truly satisfies him:

\footnotetext{
'Nat Field was made well, Will Shakespeare lived to give us his plays. But a part of you is still wounded, still angry, so there is one more thing I must tell you, to bring the healing full circle. I think Will missed you, Nat. He missed his Puck, his aerial sprite, when the sprite went to St Paul's and never came back.'... 'That play I gave you to read, The Tempest. It's about a great magician,
}

called Prospero. Will Shakespeare played him, a few times-it was the last part he ever played. And in the play, Prospero has a servant, a spirit, a sort of ethereal Puck, whose name is Ariel. No doubt a good little actor played him, a pretty light-footed boy with a sweet voice, but Ariel was written for Will Shakespeare's vanished Nat, the boy in his memory. You.'... 'At the end of The Tempest Prospero lets Ariel go free. "I shall miss thee," he says, "But still thou shalt have freedom". Go free, Nat-free of grieving. And your two poets will go with you always.'

(Cooper 2000, pp.180-1)

Having already been implicated in the production of Shakespeare's texts, and marked as a legitimate heir to this text, this information enacts a final synthesis between Nat's fear of loss and mortality, and the social and cultural value of 'Shakespeare'. In short, Nat reconciles the loss of both his own father and the historical Shakespeare, thereby accepting the reality of mortality, and is also ameliorated by a Romantic vision of immortality through art, an immortality that extends not only to Shakespeare, but to Nat himself.

Klein's text would seem to deploy a greater sense of realism in forcing Penny to engage with Shakespeare as a diverse cultural signifier, rather than as fantastic tourguide to historical London, and in fact is more consistent in its mode of narration. Penny's first-person self-reflexive narration in the form of diary entries and letters does allow the older or more informed reader to deduce ideas that Penny herself remains ignorant of, or mistaken about: the American tourist Bob/Barb's name for example, and the burgeoning romance between Lucy and Dudley. The documentary/scrapbook style of the book constantly foregrounds its own status as constructed narrative. In comparison to this self-reflexivity, we meet with a marked self-consciousness in Cooper's novel. As a narrator, Nat acknowledges his 'narrativising' of events through direct address to the reader, and in doing so, betrays an anxiety about his tale inversely proportionate to the authenticity of his relationship with Shakespeare:

if that makes you go 'Haw-haw-haw' you might as well stop reading my story right now.

(Cooper 2000, p.8) 
I have to write down the way he spoke, the way they all spoke, not as they really sounded but as I understood them. I'll use things like 'thou' and 'tha' for 'you', sometimes, just to remind you that they didn't sound like us, but I can't make you hear the real speech. It was like a thick, thick dialect, with strange vowels, strange words, strange elaborate phrases. But it was more like the speech of my home than the English of today's London or New York, so perhaps that's how I understood them and they understood me. (p.35)

The narrative is further disrupted by regular 'updates' or intrusions from a third-person omniscient narrator, giving us 'meanwhile back in contemporary London' reports. We can clearly see the diegetic purpose of these interjections, but we should also note that these are typographically and epistemologically reinforced as the voice of authority in the novel. These reports are printed in italics, otherwise only used for the transmission of Nat's unspoken thoughts, and provide adult assessments of events. In these ways they are marked as superordinate to Nat's own narrative.

A comparative reading of these texts would therefore seem to reveal Nat as the postcolonial child, whose adventures encourage child readers to understand Shakespeare in an historical context, and develop their own relationship with both the man and the plays, erasing the colonial 'baggage' of 'Shakespeare' by eliding the four centuries of accretion that have taken place around him and encouraging an immediate connection founded on an autonomous authenticity of personal culture and a recognition of shared value between themselves and Shakespeare, whereas Penny continues as a colonial child: at best she can attempt to ignore aspects of cultural heritage and attempt to establish a personal understanding of the plays, rather than Nat's strategic erasure of such cultural heritage.

The wholesale postcolonial annexing of Shakespeare that takes place in King of Shadows is emphasized by juxtaposition with Penny's piece-meal engagement with snippets from unnamed plays. Nat's engagement with origins has enabled him to accept endings; his personal quest of adventure from, and return to, home has achieved a personal and 'universal' success. His necessary Oedipal development, forestalled by his biological father's suicide, is facilitated by a cultural father, Shakespeare, but it is an immediate and living Shakespeare. Reading this in terms of the broader cultural discourses, America has successfully engaged directly with the 'father' and established itself as equal to him, taking the essential best as its own. Penny's return to origins is 'pre-Oedipal': she is not defeating but effacing the yoke of parental baggage. Similarly, Australia continues to struggle to establish and produce a Shakespeare that is at once 'authentic' and 'Australian'. That Penny does not even conceive of redefining either of these terms indicates her replication rather than repudiation of the cultural anxiety articulated by the adults around her, and evidenced in the constant remonstrations not to 'give Australia a name worse than Crocodile Dundee', (Klein 1999, p.111-2) and to view her trip to the United Kingdom as an educational experience. Nat returns home having 'saved' Shakespeare, and essentially having produced Shakespeare, while Penny returns home having learned to respect the Shakespeare handed to her. The obvious question left for the Australian child - as representative of Australian culture therefore, is how to begin to articulate an 'Australian Shakespeare'; one which negotiates between the discourses of 'Shakespeare' and nationality as constituent elements of cultural identity. 


\section{END-NOTES}

1. Cooper was born and raised in Great Britain, but she has lived for the majority of her life in the United States. This novel features an American protagonist, and normalizes American culture as central reference point, indicating in my opinion an intended American readership.

2. We may also note that the contemporary texts seem to replicate not only the general veneration of Shakespeare, but also replicate the implied gender response roles. The Australian female is a far more passive recipient than the American male. This may indicate that not only national but gendered ideologies are being deployed in these texts.

3 Arby, the director of the Dream in contemporary London, is a mystical figure who may in fact be a reincarnation of, but is certainly marked as an inheritor of, Richard Burbage. This is revealed by Nat's Aunt Jennifer, who we may also note was originally responsible for interesting Nat in the theatre at all: "'Arby," said Aunt Jen with mild interest. "The initials, I suppose. RB. Richard Babbage.”' (p.175).

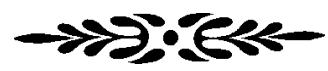

\section{REFERENCES}

Bloom, Harold (1998) Shakespeare: The Invention of the Human. New York, Riverhead Books.

Bradford, Clare (1996) 'Centre and edges: postcolonial literary theory and Australian picture books', in Clare Bradford (ed) Writing the Australian Child: Texts and Contexts in Fictions for Children. Nedlands, WA, University of Western Australia Press, pp.92-110.

Bristol, Michael D. (1990) Shakespeare's America, America's Shakespeare. London, Routledge.
- (1996) Big-Time Shakespeare. London, Routledge.

Burt, Richard (1998) Unspeakable ShaXXXspeares:Queer Theory \& American Kiddie Culture. New York, St. Martin's Press.

Cartelli, Thomas (1999) Repositioning Shakespeare: National Formations, Postcolonial Appropriations. London, Routledge.

Cooper, Susan (2000) King of Shadows. Harmondsworth, Puffin Books.

Craven, Peter (2001) 'Shakespeare in Australia', Australian Book Review, September: 27-32.

Freedman, Barbara (1989) 'Misrecognizing Shakespeare', in N.N. Holland, S. Homan and B.J. Paris (eds) Shakespeare's Personality. Berkeley, University of California Press, pp. 244-60.

Golder, John and Richard Madelaine (2001) 'To dote thus on such luggage': appropriating Shakespeare in Australia', in J. Golder and R. Madelaine (eds) O Brave New World: Two Centuries of Shakespeare on the Australian Stage. Sydney, Currency Press, pp.1-16.

Klein, Robin (1999) Penny Pollard's Passport. Sydney, Hodder Headline Australia.

Lamb, Charles and Mary Lamb (1953) Tales From Shakespeare. M. Armstrong (ed) London, Collins.

Marowitz, Charles (1991) Recycling Shakespeare. Hampshire, MacMillan Education.

Neill, Michael (1998) 'Post-colonial Shakespeare? Writing away from the centre', in A. Loomba and M. Orkin (eds) Post-Colonial Shakespeares. London, Routledge, pp.164-85. 
Nesbit, Edith (c1907) Beautiful Stories from Shakespeare: Being a Choice Collection from the World's Greatest Classic Writer Wm. Shakespeare. New York, Weathervane Books.

Osborne, Laurie E. (1997) 'Poetry in motion: animating Shakespeare', in L. Boose and R. Burt (eds) Shakespeare the Movie: Popularizing the Plays on Film, TV, and Video. London, Routledge.

Stephens, John (1992) Language and Ideology in Children's Fiction. London, Longman.

Stephens, John, and Robyn McCallum (1998) Retelling Stories, Framing Culture: Traditional Story and Metanarratives in Children's Literature. New York, Garland.

\section{BIOGRAPHICAL NOTE}

Erica Hately is a graduate student in the School of Literary, Visual and Performance Studies at Monash University. She has published on the work of Julian Barnes and Martin Amis and is currently researching the appropriation of Shakespeare's Macbeth in contemporary popular culture.

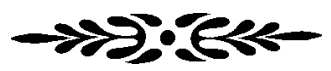

